\title{
PEMBUATAN SIGN SYSTEM DI KAWASAN WISATA KAMPUNG URUG, BOGOR - JAWA BARAT
}

\author{
MRR. Tiyas Maheni ${ }^{1}$, Irpan Saripudin ${ }^{2)}$, Anggi Anggarini ${ }^{3)}$, Susilawati \\ Thabrani ${ }^{4)}$, Dwi Agnes Natalia ${ }^{5}{ }^{5}$, Sari Puspita Dewi ${ }^{6}$. \\ Politeknik Negeri Jakarta \\ *tiyas.maheni@grafika.pnj.ac.id
}

\begin{abstract}
ABSTRAK
Kampung Urug memiliki potensi untuk menjadi destinasi wisata. Melihat potensi kearifan budaya dan historis Kampung Urug, maka destinasi wisata Kampung Urug dapat dikembangkan menjadi daerah wisata adat. Akan tetapi kondisi kesiapan kampung Urug untuk menjadi kampung wisata adat masih kurang, salah satunya terlihat dari minimnya sign system penunjuk arah yang membuat pengunjung kurang maksimal dalam mengenal keunikan budaya Kampung Urug. Terkait dengan hal tersebut, Tim Pengabdian kepada Masyarakat Program Studi Desain Grafis TGP-PNJ membuat desain sign system yang terpadu dengan konsep yang menguatkan identitas kawasan wisata Kampung Urug. Metode yang dilakukan adalah dengan melaksanakan riset terhadap kebutuhan area lokasi wisata kawasan wisata Kampung Urug lalu menentukan fasilitas umum apa saja yang akan dipresentasikan dalam bentuk sign system, dilanjutkan pembuatan alternatif desain sign system, proses produksi dan pemasangan sign system. Dalam pengabdian kepada masyarakat ini akan diberikan seperangkat sign system kepada pengelola Kampung Urug. Kedepannya diharapkan para pengunjung kawasan wisata Kampung Urug dapat semakin mudah mengidentifikasi lokasi yang dituju, dan akhirnya Kawasan Wisata Kampung Urug dapat dijelajahi dengan baik oleh para pengunjung dan citra Kampung Urug sebagai kampung adat semakin dikenal masyarakat Indonesia.
\end{abstract}

Keywords :

sign system, desain grafis, Kampung Urug, wisata

\section{PENDAHULUAN}

\section{LATAR BELAKANG}

Kampung adat Urug yang berlokasi di Desa Urug Kecamatan Sukajaya Kabupaten Bogor Propinsi Jawa Barat menjadi destinasi wisata budaya bagi pelancong yang ingin menemukan alternatif rekreasi unik di Sukajaya. Tatanan masyarakat yang bertahan dengan tradisi dengan keramah tamahan masyarakatnya menjadi daya tarik tersendiri saat menginjakkan kaki di kampung adat Urug. Kondisi alam yang asri dan masih terjaga dengan latar Gunung Manapa menambah pemandangan eksotis yang menyejukkan.

Secara administratif, Kampung Urug termasuk ke dalam wilayah Desa Kiarapandak, Kecamatan Sukajaya, Kabupaten Bogor. Luas wilayahnya berbatasan dengan daerah-daerah sekitarnya, yaitu di sebelah utara berbatasan dengan Tajur; sebelah selatan berbatasan dengan Mandaya; sebelah barat berbatasan dengan Pasirmadang; dan di sebelah timur berbatasan dengan Pasir Peuteuy. Jarak tempuh Kampung Urug dari Ibukota provinsi Jawa Barat lebih kurang 165 kilometer ke arah barat. Jarak dari Ibukota Kabupaten Bogor Iebih kurang 48 kilometer, dari kota kecamatan Sukajaya lebih kurang 6 kilometer, sedangkan dari kantor Desa Kiarapandak Iebih kurang 1,2 kilometer. Kondisi jalan dari kantor kecamatan Sukajaya ke Kampung Urug berbelok-belok naik turun mengikuti lereng bukit dengan badan jalan yang sempit. Sepanjang jalan dari kantor kecamatan ke kantor kepala desa Kiarapandak sudah beraspal, namun sebagian besar rusak berat. Jalan dari kantor desa ke kampung Urug, beraspal dan kondisinya cukup baik.

Menurut data Dinas Kebudayaan dan Pariwisata Kabupaten Bogor, Kampung Urug mempunyai tingkat kunjungan wisata rata - rata 80 - 100 orang setiap bulan dan jika pada hari - hari besar bisa mencapai 600 - 800 orang per hari. Hal ini menunjukkan bahwa Kampung Urug memiliki potensi untuk menjadi destinasi wisata. Melihat potensi kearifan budaya dan historis Kampung Urug, maka destinasi wisata Kampung Urug dapat dikembangkan menjadi daerah wisata adat. Namun, berdasarkan survey awal yang dilakukan pada tanggal 19 Maret 2018, kondisi kesiapan kampung 
Urug untuk menjadi kampung wisata adat masih kurang. Baik aparatur pemerintahan desa maupun lembaga kemasyarakatan Desa Urug belum memaksimalkan potensi wisata yang ada di Kampung Urug. Hal ini salah satunya terlihat dari minimnya sign system penunjuk arah dan media informasi membuat pengunjung kurang maksimal dalam mengenal keunikan budaya Kampung Urug. Sign system yang ada selain tidak lengkap juga belum adanya keseragaman desain pada sign sistem yang sesuai dengan identitas kawasan wisata kampung Urug.

Kebutuhan akan informasi saat ini semakin tinggi. Dibutuhkan suatu sistem informasi terpadu yang sesuai dengan esensial environment di mana informasi tersebut ditempatkan. Tidak terkecuali di tempat pariwisata. Para pengunjung/wisatawan membutuhkan media informasi yang menggunakan simbol grafis dalam menggambarkan posisi suatu tempat, arah menuju obyek wisata, petunjuk atau instruksi tentang suatu acara digelar di sebuah kawasan wisata. Para wisatawan memerlukan misalnya denah dan peta lokasi keberadaan obyek wisata lengkap dengan sign system yang mampu memandu mereka menuju lokasi dan wahana yang diinginkan. Sign system berguna sebagai pentunjuk arah, yang dapat digunakan sebagai pengatur mobilitas secara jelas dan akurat.

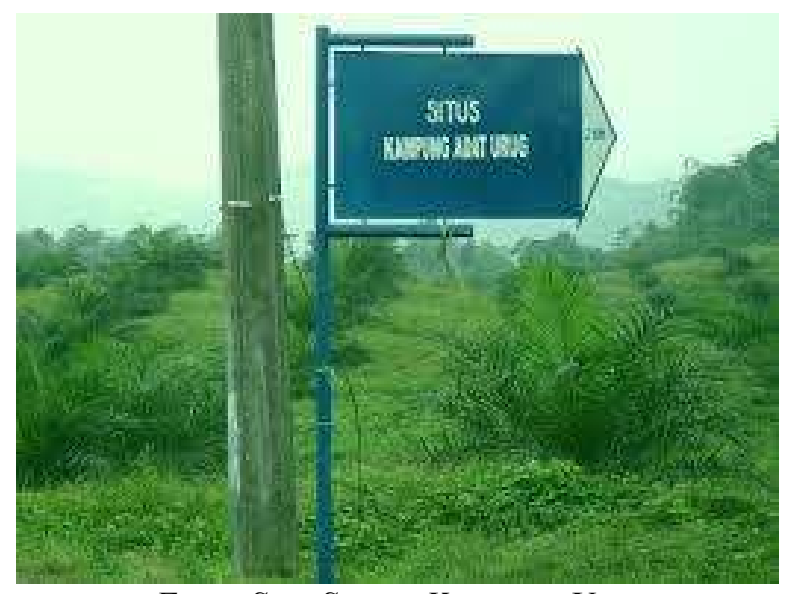

Foto : Sign System Kampung Urug

Keberadaan Kampung Urug, selain dapat menjadi media edukasi dalam menjaga kelestarian budaya, juga sangat membantu kehidupan perekonomian masyarakat sekitar. Maka dengan pembuatan desain sign system diharapkan dapat semakin meningkatkan jumlah pengunjung, sehingga tingkat perekonomian masyarakat terutama yang tinggal di kawasan Kampung Urug ikut meningkat juga.

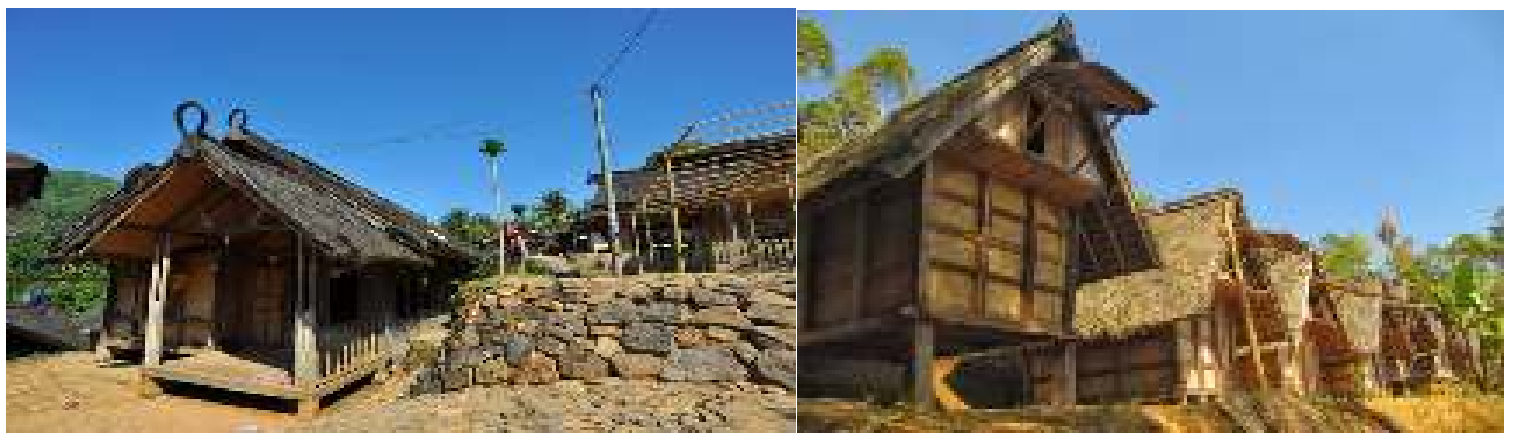




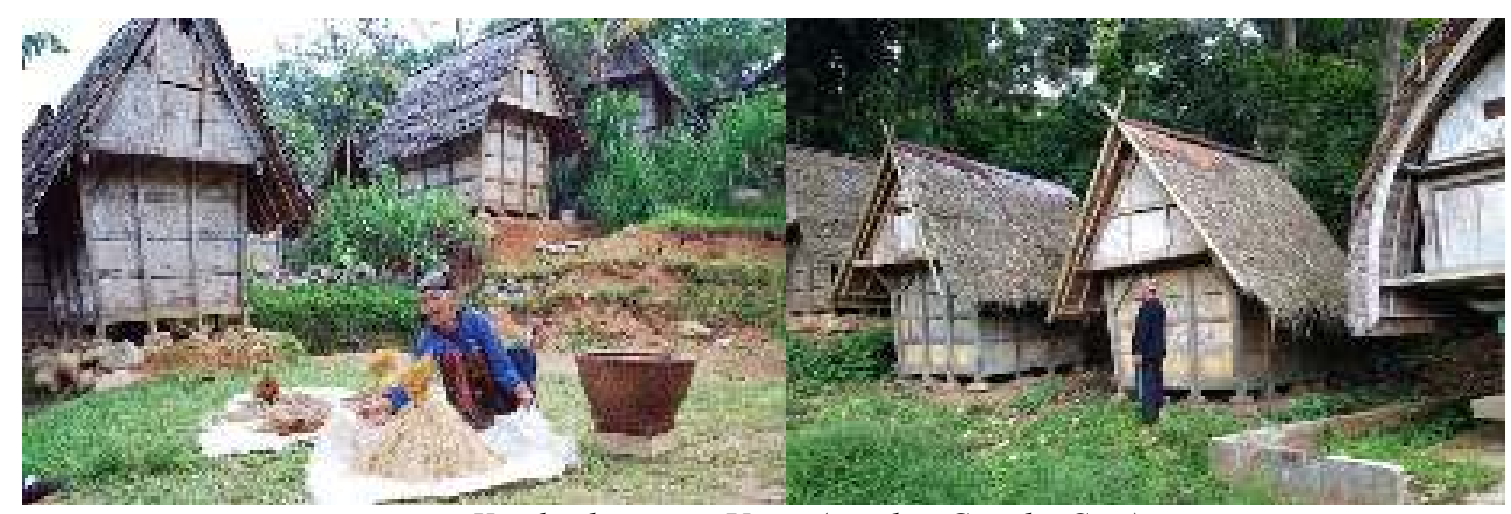

Kondisi kampung Urug ( sumber Google. Com)

\subsection{Permasalahan Mitra.}

Kondisi kesiapan Kampung Urug untuk menjadi kampung wisata adat masih kurang. Baik aparatur pemerintahan desa maupun lembaga kemasyarakatan desa Urug belum memaksimalkan potensi wisata yang ada di Kampung Urug. Hal ini salah satunya terlihat dari minimnya sign system penunjuk arah dan media informasi membuat pengunjung kurang maksimal dalam mengenal keunikan budaya Kampung Urug. Sign system yang ada selain tidak lengkap juga belum adanya keseragaman desain pada sign sistem yang sesuai dengan identitas kawasan wisata Kampung Urug.

\subsection{Tujuan Kegiatan Pengabdian kepada masyarakat}

Tujuan dari kegiatan pengabdian kepada masyarakat ini adalah untuk membuat sign sytem di kawasan wisata Kampung Urug. Sign system atau sistem penanda ini akan memudahkan pengunjung untuk menemukan fasilitas yang ada di dalam lokasi wisata Kampung Urug.

\section{METODE}

Metode yang dilaksanakan dalam kegiatan pengabdian masyarakat ini adalah sebagai berikut :

1. Pelaksanaan riset terhadap kebutuhan area lokasi wisata kawasan wisata Kampung Urug. Riset ini dilakukan dengan melakukan wawancara kepada kepala adat Kawasan Kampung Urug untuk mengetahui kebutuhan penunjuk arah dan penanda lokasi dan wawancara kepada pengunjung untuk mengetahui kesulitan mereka selama berwisata di kawasan Kampung Urug. Riset juga dilakukan dengan melakukan pengamatan langsung (observasi) pada sign system yang sudah ada sebelumnya, fasilitas umum objek wisata yang ada serta nuansa area untuk mendapatkan gambaran umum mengenai kondisi geografis

2. Hasil riset yang telah didapat dan dikumpulkan kemudian dianalisa untuk menentukan fasilitas umum apa saja yang akan direpresentasikan dalam bentuk sign system, dan untuk menentukan tema desain yang sesuai dengan karakter lokasi wisata kawasan Kampung Urug. Berdasarkan tema desain, kemudian dibuat konsep visual untuk perancangan desain sign system. Rancangan desain sign system dibuat dalam beberapa alternatif desain sekaligus mencakup pilihan bahan material yang akan diterapkan, serta usulan mengenai lokasi penempatan sign system di area lokasi wisata.

3. Selanjutnya, alternatif desain sign system serta perencanaan bahan material dan usulan lokasi penempatan tersebut diusulkan kepada kepala adat dan perangkat desa. Pemilihan desain akhir didapatkan melalui hasil diskusi, demikian juga halnya dengan perencanaan bahan material dan lokasi penempatan sign system.

4. Setelah didapatkan kesepakatan, dilakukan proses produksi sign system dengan menggunakan bahan material yang disetujui. Kemudian, sign system tersebut akan ditempatkan pada area lokasi wisata Kampung Urug.

\section{HASIL DAN PEMBAHASAN}


Pembuatan sign system di Kampung Urug, Sukajaya, Kabupaten Bogor Jawa Barat sebagai bentuk kegiatan pengabdian kepada masyarakat oleh Program Studi Desain Grafis Jurusan Teknik Grafika dan Penerbitan dilaksanakan sebagai berikut :

\section{Kebutuhan petunjuk arah}

Berdasarkan riset yang telah dilakukan akhirnya diputuskan bersama dengan kepala desa Kampung Urug untuk membuat petunjuk arah yang diletakkan pada posisi strategis yaitu diletakkan di jalan masuk Kampung Adat Urug dan rumah pemangku adat.

\section{Desain Sign System}

Pada tahap ini dibuat beberapa alternatif desain yang nantinya akan dipilih untuk diproduksi. Beberapa alternatif desain tersebut adalah sebagai berikut :

\section{a. Alternatif desain 1}

Alternatif desain ini menggunakan pendekatan stilasi dari bentuk ornamen tarali dan bentuk leuwit yang dijadikan huruf serta warna merah marun sebagai simbol darah wanita yang menjadi pantangan atau pamali yang dipercayai masyarakat kampung urug secara turun temurun.
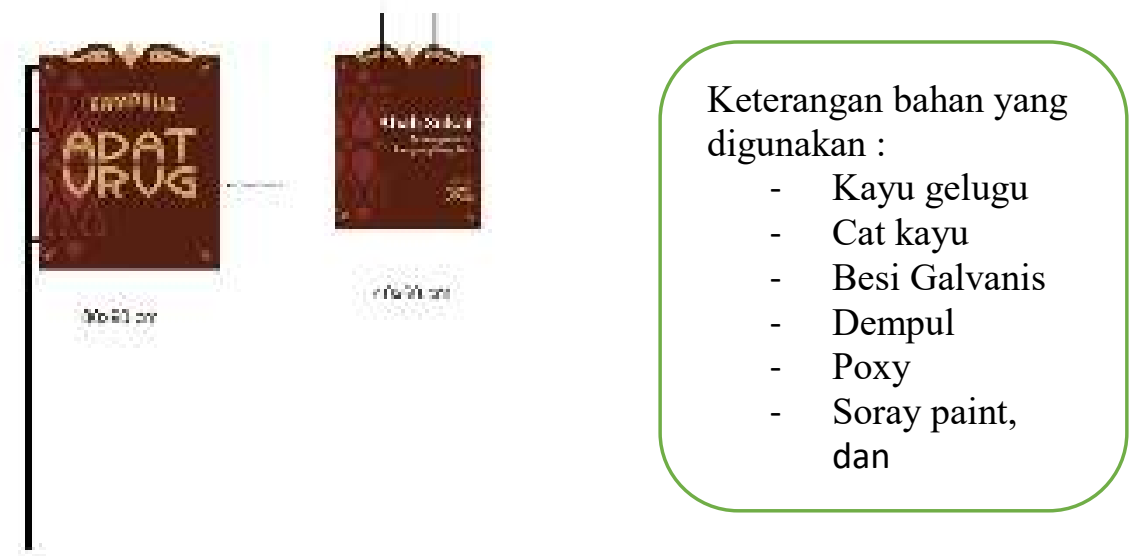

b. alternatif desain 2

Alternatif desain ini menggunakan konsep dengan pendekatan stilasi mahkota Prabu Siliwangi dan ornamen tarali. Penggunaan warna coklat sebagai lambang bersatu dengan alam, menggunakan huruf diadaptasi dari aksara Sunda. 


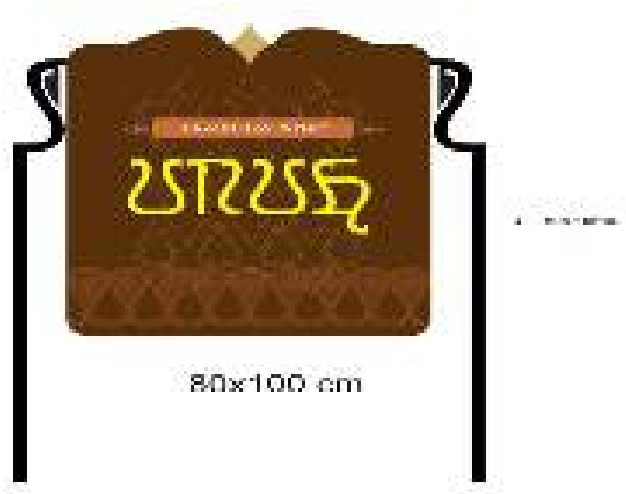

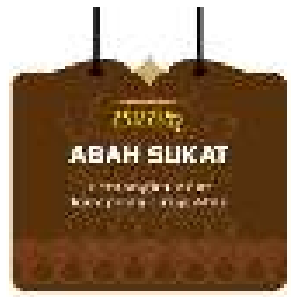

$10 \times 80$ जाI

keterangan bahan yang digunakan :

- Kayu mahoni

- Cat kayu

- Besi galvanis

- Dempul

- Poxy

- Spray paint

- Varnish kayu

- Rantai besi

\section{c. Alternatif desain 3}

Alternatif desain ini menggunakan konsep dengan pendekatan ornamen pada arsitektur yang terdapat pada rumah para pemangku adat yaitu tarali yang mempunyai filosofi tidak ada atas dan bawah, juga kontur geografis yang berada di pegunungan tropis. Hijau dan padi sebagai lambang kesuburan dan kemakmuran. Stilasi bangunan leuwit (lumbung padi) dijadikan bentuk huruf dengan warna yang mencolok.

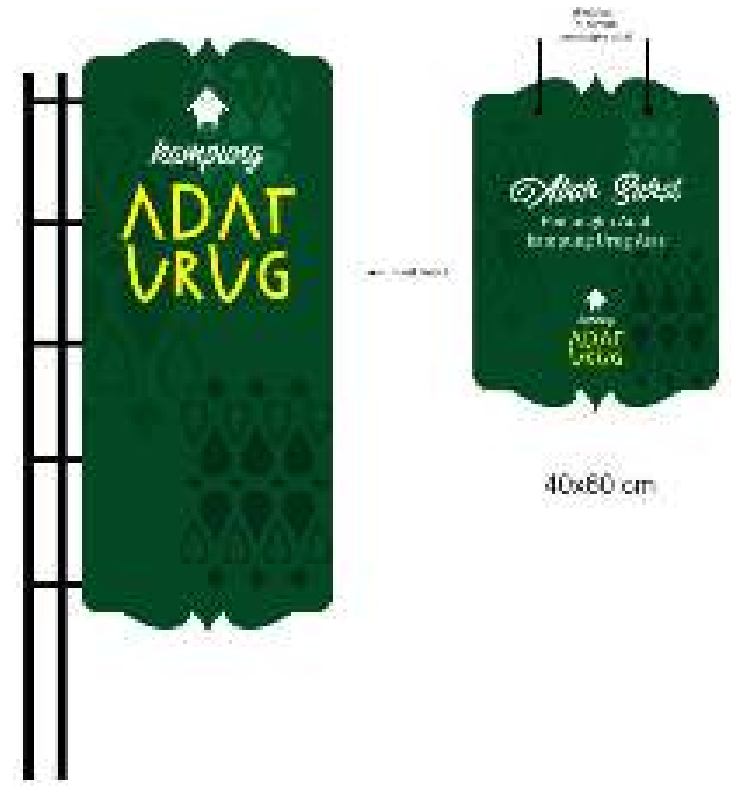


keterangan bahan yang digunakan :

- Papan multipleks

- Besi galvanis

- Cat kayu

- Cutting sticker

- Dempul

- Poxy

- Spray paint

- Varnish kayu

- Rantai besi

\section{d. Alternatif desain 4}

Alternatif desain ini hampir sama dengan alernatif desain ke 3, yaitu menggunakan konsep dengan pendekatan ornamen pada arsitektur yang terdapat pada rumah para pemangku adat yaitu tarali yang mempunyai filosofi tidak ada atas dan bawah, kontur geografis yang berada di pegunungan tropis. Hijau dan padi sebagai lambang kesuburan dan kemakmuran. Stilasi bangunan leuwit (lumbung padi) dijadikan bentuk huruf dengan warna yang mencolok. Akan tetapi ada sedikit tambahan variasi dan bahan yang digunakan berbeda

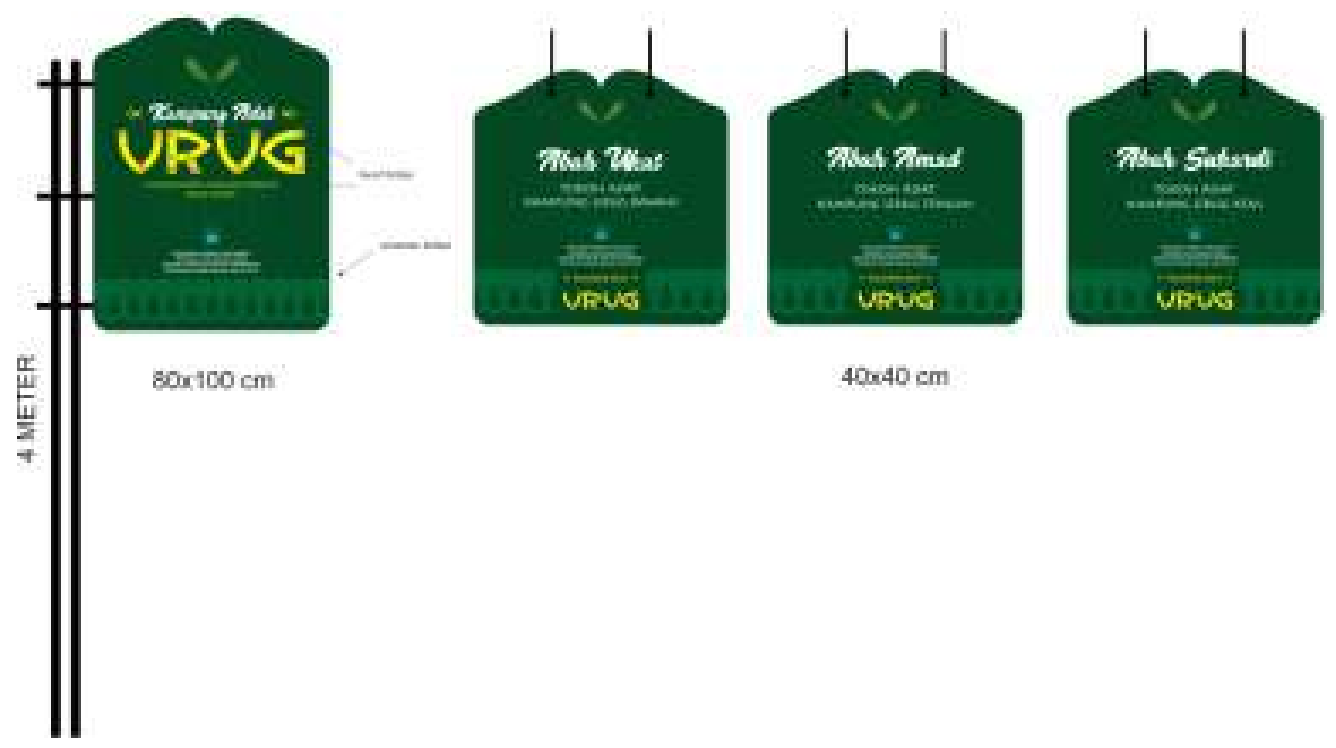

Bahan yang digunakan:

- Mika warna

- Cutting sticker

- Besi

- Galvanis

- Spray paint

- Dempul

- Poxy

- Rantai

Dari keempat alternatif desain yang telah dibuat di atas, alternative desain nomor 4 (empat) yang terpilih dengan berbagai pertimbangan baik bahan, estetik maupun artistik.

3. Tahap Produksi

Proses produksi atau pembuatan penunjuk arah dilakukan selama satu bulan. Meliputi pembuatan desain huruf yang diambil dengan pendekatan ornamen khas Kampung Adat Urug dan leuwit yang 
ada di Kampung Adat Urug. Penunjuk arah dibuat menggunakan material acrylic dengan teknologi laser untuk membuat huruf timbul dan bentuk dari penunjuk arah kemudian untuk ornamen dan beberapa bagian huruf dan logo kampus dengan cutting sticker. Hasilnya dapat dilihat pada gambar di bawah ini.
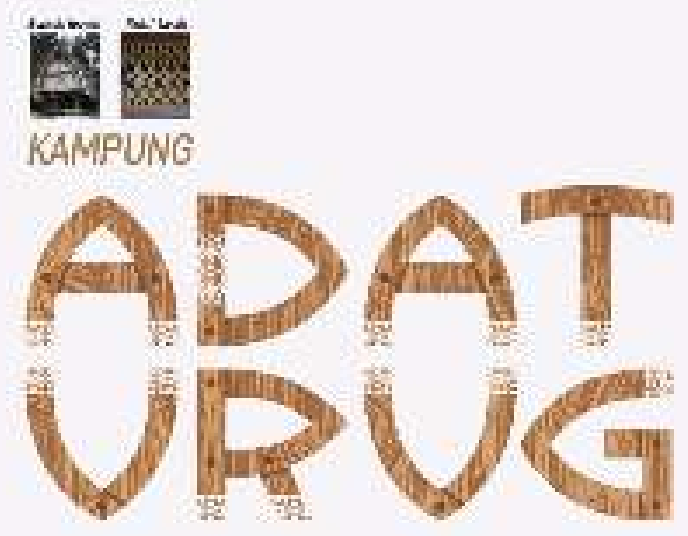

Desain huruf dan pemotongan huruf dengan laser

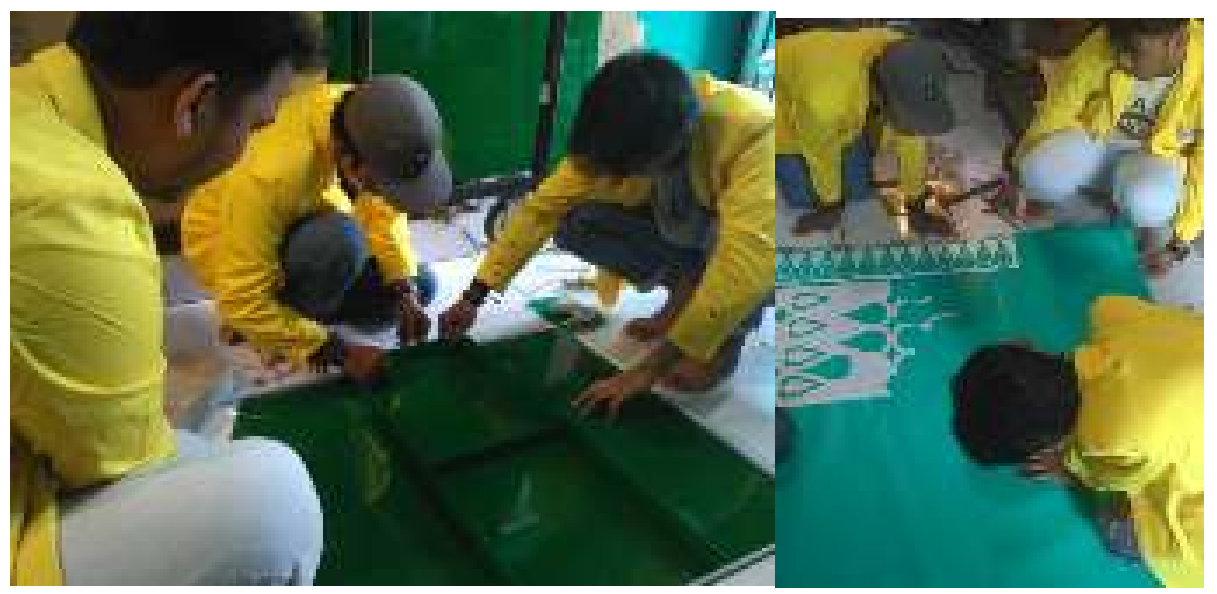

Pembentukan akrilik dan cutting sticker

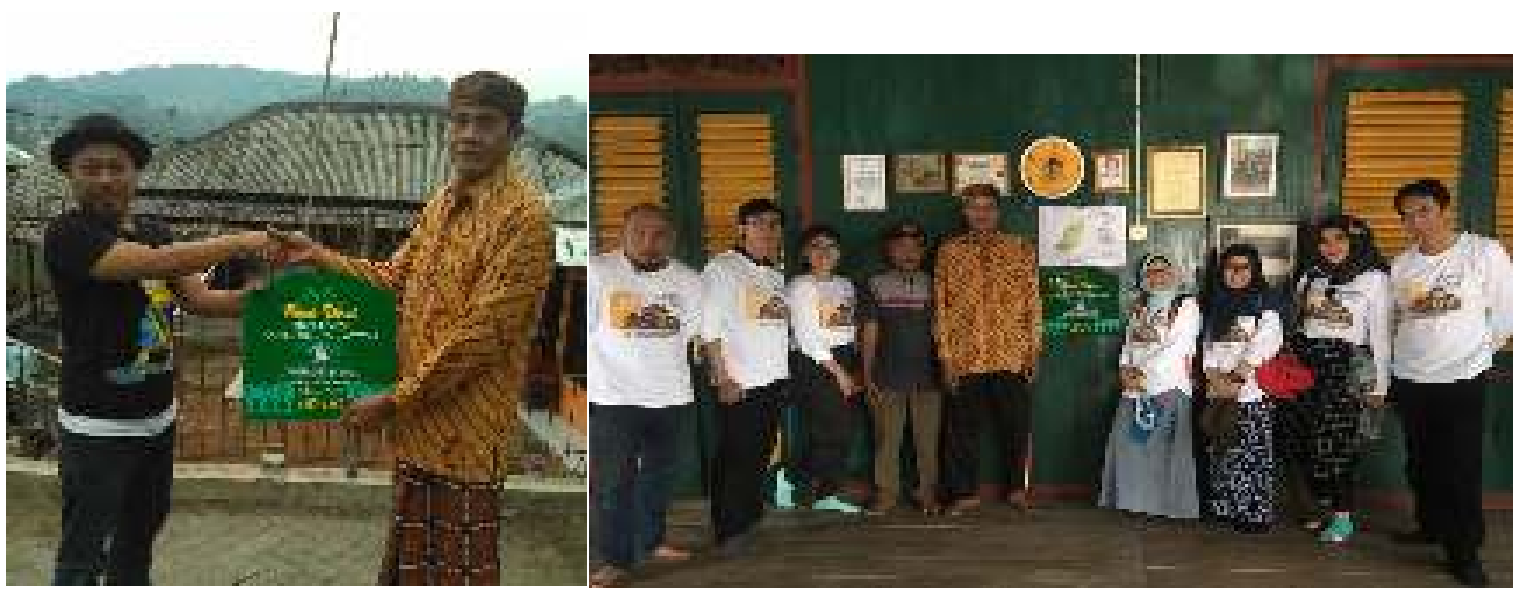

Serah Terima Sign System Secara Simbolis 
4. Penempatan Sign system

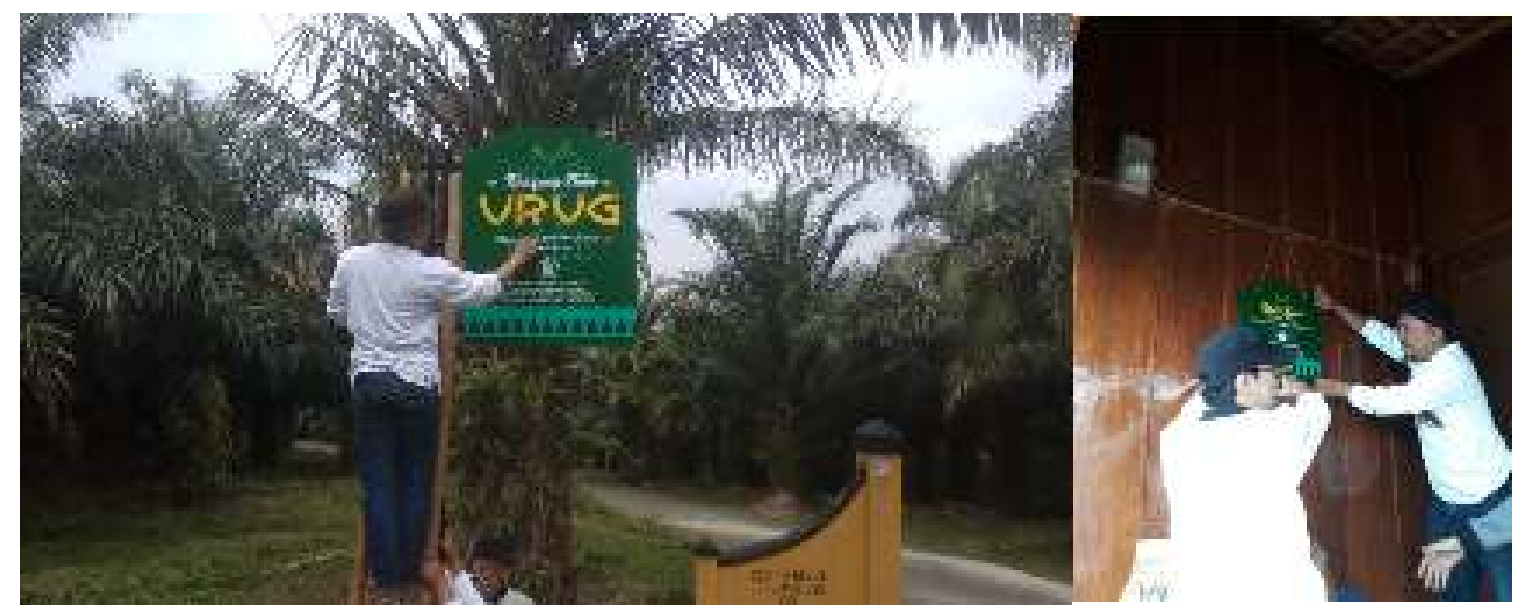

Pemasangan sign system di jalan utama dan di rumah adat

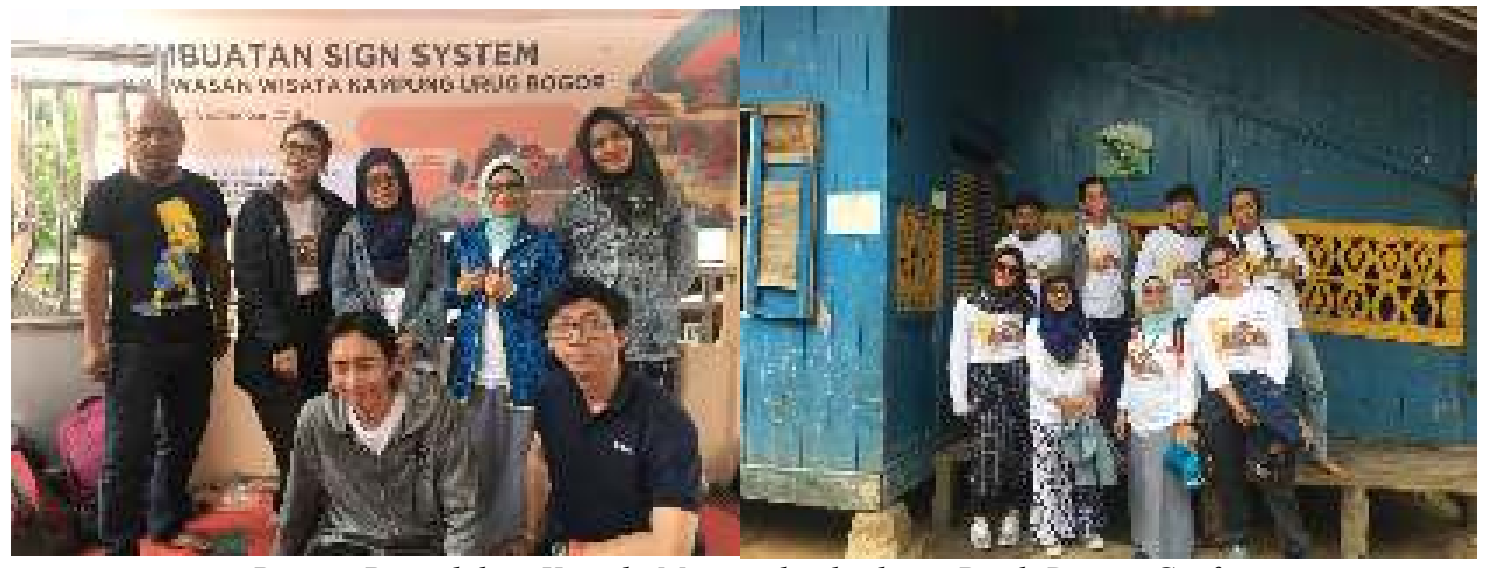

Panitia Pengabdian Kepada Masyarakat berbasis Prodi Desain Grafis

\section{SIMPULAN}

Melalui kegiatan pengabdian kepada masyarakat ini, kawasan wisata Kampung Urug akhirnya memiliki sign system berupa penunjuk arah utama dan identitas rumah adat Kampung Urug dengan desain yang sesuai dengan identitas kawasan wisata Kampung Urug. Hal ini dapat semakin menguatkan dan mampu merepresentasikan ciri khas dari kawasan wisata Kampung Urug. Selain itu, dengan adanya sign system ini, juga dapat membantu pengunjung menuju lokasi yang diinginkan. Dengan demikian diharapkan dapat semakin meningkatkan jumlah pengunjung di area wisata Kampong Urug.

\section{DAFTAR PUSTAKA}

1. Calori, Chris. 2015. Signage and Wayfinding Design: A Complete Guide to Creating Environmental Graphic Design Systems, Wiley, New York. 
2. Galindo, Michelle, 2011. Signage Design (Architecture in focus), Braun

3. Uebele, Andreas, 2007. Signage Systems and Information Graphics. Thames and Hundson, London.

4. Winn, Wendy, 2014. Increasing Accessibility With Avisual Sign System: A Case Study, Sage Journal.

5. https://www.amazon.com/Signage-systems-information-Graphics-Andreas/dp/0500513791 